\title{
Atmospheric mercury pollution around a chlor-alkali plant in Flix (NE Spain): an integrated analysis
}

\author{
José M. Esbrí • Miguel Angel López-Berdonces • \\ Sergio Fernández-Calderón • Pablo Higueras • Sergi Díez
}

Received: 7 March 2014 / Accepted: 6 July 2014 / Published online: 19 July 2014

(C) Springer-Verlag Berlin Heidelberg 2014

\begin{abstract}
An integrated analysis approach has been applied to a mercury $(\mathrm{Hg})$ case study on a chlor-alkali plant located in the Ebro River basin, close to the town of Flix (NE Spain). The study focused on atmospheric $\mathrm{Hg}$ and its incorporation in soils and lichens close to a mercury cell chlor-alkali plant (CAP), which has been operating since the end of the 19th century. Atmospheric Hg present in the area was characterized by means of seven total gaseous mercury (TGM) surveys carried out from 2007 to 2012. Surveys were carried out by car, walking, and at fixed locations, and covered an area of some $12 \mathrm{~km}^{2}$ (including the CAP area, the village in which workers live, Flix town, and the Sebes Wildlife Reserve). Finally, an atmospheric $\mathrm{Hg}$ dispersion model was developed with ISC-AERMOD software validated by a lichen survey of the area. The results for the atmospheric compartment seem to indicate that the Flix area currently has the highest levels of $\mathrm{Hg}$ pollution in Spain on the basis of the extremely high average concentrations in the vicinity of the CAP $\left(229 \mathrm{ng} \mathrm{m}^{-3}\right)$. Moreover, the $\mathrm{Hg}^{0}$ plume affects Flix town center to some extent, with values well above the international thresholds for residential areas. Wet and dry Hg deposition reached its highest values on the banks of the Ebro River, and this contributes to increased soil contamination (range 44$12,900 \mathrm{ng} \mathrm{g}^{-1}$, average $775 \mathrm{ng} \mathrm{g}^{-1}$ ). A good fit was obtained
\end{abstract}

Responsible editor: Philippe Garrigues

J. M. Esbrí · M. A. López-Berdonces · S. Fernández-Calderón · P. Higueras

Departamento de Ingeniería Geológica y Minera and Instituto de Geología Aplicada, Universidad de Castilla-La Mancha, E.I.M.I. Almadén, 13400 Almadén, Ciudad Real, Spain

\section{S. Díez $(\square)$}

Environmental Chemistry Department, Institute of Environmental Assessment and Water Research, IDAEA-CSIC, Jordi Girona, 18-26, 08034 Barcelona, Spain

e-mail: sergi.diez@idaea.csic.es between anomalous areas indicated by lichens and the dispersion model for 1 year.

Keywords Flix · Chlor-alkali plant · Dispersion modeling · Soils $\cdot$ Sediments $\cdot$ TGM

\section{Introduction}

Mercury $(\mathrm{Hg})$ is one of the most toxic elements in almost all its forms, even in trace level concentrations, as a result of its bioavailability, mobility, bioaccumulation, and high biomagnification factor in the food chain, particularly in fish at trace levels. Mercury has received special attention because methylmercury (MeHg), the most toxic form of mercury, has proven toxic effects and can cause severe neurological damage to humans and wildlife (Clarkson and Magos 2006; Diez 2009; Mergler et al. 2007). Bellanger et al. (2013) estimated the monetary value of the prevention of this neurotoxin: "The total annual benefits of exposure prevention within the EU were estimated at more than 600,000 IQ (Intelligence Quotient) points per year, corresponding to a total economic benefit between $€ 8,000$ million and $€ 9,000$ million per year".

Atmospheric mercury has both natural and anthropogenic sources. Natural sources of $\mathrm{Hg}$ emission account for $5,207 \mathrm{Mg} \mathrm{yr}^{-1}$, while the anthropogenic contribution is estimated to be about $2,320 \mathrm{Mg} \mathrm{yr}^{-1}$, of which more than $95 \%$ has been released during the last century (Pirrone et al. 2010). The main natural sources of $\mathrm{Hg}$ relate to evasion from marine surface waters, biomass burning, and volcanic emissions. Anthropogenic sources, which include a large number of industrial point sources, mainly arise from fossil-fuel fired power plants, artisanal small-scale gold mining, the manufacture of non-ferrous metals, cement production, waste disposal, and the chlor-alkali industry (UNEP 2013; Selin 2009). 
The chlor-alkali industry is the third major Hg user worldwide, with higher use only in small-scale gold mining followed by vinyl chloride monomer production (UNEP 2010). Many plant operators have phased out this technology and converted to the more energy-efficient and mercury-free membrane process (Pacyna et al. 2010). The worldwide activity of chlor-alkali plants (CAP), in which elemental $\mathrm{Hg}$ is used for the production of chlorine and caustic-soda, was estimated to be responsible for the emission of $46.8 \mathrm{t}$ of $\mathrm{Hg}$ in 2005 (Pacyna et al. 2010). In Europe, this amount has now significantly decreased due to recent legislation, which imposes the use of alternative and less polluting processes (i.e., the membrane cell process). According to the World Chlorine Council (WCC 2013), the number of plants and the mercurycell-based production capacity has shown a worldwide decrease. The output from plants decreased from $9.1 \times 10^{6}$ to $4.9 \times 10^{6} \mathrm{t}$ over the period 2002-2012 (-45\%) and the mercury-cell-based capacity also decreased from 9.1 to 4.9 million tonnes ( $-47 \%)$. Likewise, global $\mathrm{Hg}$ emissions show a similar trend since they have been substantially reduced in the period 2002-2012. These emissions decreased by around $75 \%$, i.e., from 24.6 to about $6.2 \mathrm{t} \mathrm{yr}^{-1}$.

Hg-electrolysis technology has been studied worldwide despite the fact that it has a negative impact on the environment (Biester et al. 2002; Busto et al. 2013; Degetto et al. 1997; Frentiu et al. 2013; Grangeon et al. 2012; Guedron et al. 2013; Landis et al. 2004; Montuori et al. 2006; Nik et al. 2012) and the use of elemental $\mathrm{Hg}$ as a cathode in chlor-alkali plants has been forbidden in Europe since 2008 (EC 2008). Howev$\mathrm{er}$, some facilities benefit from specific authorizations and will continue to exist until 2020 (EC 2004). This is the case for the Flix CAP, which is currently the third largest chlorine producer in Spain, with a capacity of $115,200 \mathrm{t} \mathrm{Cl}_{2}$ per year (EuroClor 2012). At present, the major environmental concern in the lower course of the Ebro River is the presence of a deposit of $7 \times 10^{5} \mathrm{~m}^{3}$ of hazardous industrial solid waste on the right bank of the river (Fig. 1) in front of Flix CAP. The deposit occupies an area of 9 ha, and high $\mathrm{Hg}$ concentrations were measured in the lower depth $\left(440 \mathrm{mg} \mathrm{kg}^{-1}\right)$ and surface sediments $\left(170 \mathrm{mg} \mathrm{kg}^{-1}\right)$ (Grimalt et al. 2003). The impact of $\mathrm{Hg}$ pollution in aquatic organisms such as local populations of molluscs (Carrasco et al. 2008, 2011a) and fish (Navarro et al. 2009; Carrasco et al. 2010, 2011b) has been evaluated. Mercury species were detected in piscivorous $\left(\mathrm{THg}=0.848 \mu \mathrm{g} \mathrm{g}^{-1}\right.$ wet weight (ww); $\mathrm{MeHg}=0.672 \mu \mathrm{g} \mathrm{g}^{-1} \mathrm{ww}$ ), non-piscivorous fish ( $\mathrm{THg}=0.305 \mu \mathrm{g} \mathrm{g}^{-1} \mathrm{ww} ; \mathrm{MeHg}=0.278 \mu \mathrm{g} \mathrm{g}^{-1} \mathrm{ww}$ ), and zebra mussels (THg, 0.02 to $0.81 \mu^{-1} g^{-1}$ ww; $\mathrm{MeHg}, 0.22$ to $0.60 \mu \mathrm{g} \mathrm{g}^{-1}$, with the latter being the highest concentrations ever reported). Surprisingly, pollution associated with $\mathrm{Hg}$ in air, soils, and plants has seldom been studied in this area.

The aim of the work described here was to characterize the $\mathrm{Hg}$ cycle around these facilities. For this purpose, we evaluated data for $\mathrm{Hg}$ in air, soils, sediments, and lichens and also modeled gaseous mercury dispersion patterns. The results will be useful for risk assessments and will provide guidance for other ways to minimize exposure to the local population.

\section{Materials and methods}

\section{Study area}

The present study was undertaken in the Flix CAP and its surrounding area (Figs. 1 and 2a). The Flix dam $\left(41^{\circ} 23^{\prime} \mathrm{N}\right.$, $0^{\circ} 55^{\prime} \mathrm{E}$ ) is located in the Ebro River, and it is relatively small $\left(\right.$ area $=320 \mathrm{~km}^{2}$, volume $=11 \mathrm{hm}^{3}$ ) with a very short water residence time ( 0.15 days), thus preserving some of the river properties. The Flix area includes the village of Flix (ca. 5,000 inhabitants) and the CAP, which has been producing chlorinated solvents since the end of the 19th century, on one bank of the Flix reservoir. Surveys were also performed on the opposite river bank, which is considered to be relatively unpolluted, where a nature reserve (Sebes Wildlife Reserve) is located. It should be highlighted that due to the possibility of the disturbance of the contamination downstream and the risk of reaching the Ebro Delta Natural Park, there is a need to remove the chemical contamination from the Flix dam. The adopted solution was to create a working site, remove the waste, treat the waste, and transport it to a dumping area. At present, the hazardous waste remains confined and the river flows mainly through the left bank of the reservoir.

\section{Hg Surveys in the Flix area}

Different surveys were carried out in the Flix area with the aim of characterizing mercury contents in the air-soil system (Fig. 2a). Atmospheric $\mathrm{Hg}$ emissions and its dispersion pattern was studied by means of seven total gaseous mercury (TGM) surveys (Table 1) carried out between 2007 and 2012, including more than 145,000 TGM determinations. Data were obtained by Zeeman effect Atomic Absorption Spectrometry with High Frequency Modulation technique (ZAAS-HFM), using a number of LUMEX-RA-915 series devices (Sholupov et al. 2004). The sampling strategies were based on the ability of these devices to obtain one mercury measurement per second over a period of more than $48 \mathrm{~h}$. The range of measurements was 2-30,000 $\mathrm{ng} \mathrm{m}^{-3}$ at a flow rate of $20 \mathrm{~L} \mathrm{~min}^{-1}$, and the accuracy during this work was $95-97 \%$. The sampling method used to measure mercury emissions from the CAP and its dispersion in the surrounding area was performed by car and walking; geographic location data were obtained using a Garmin GPS Map 60CSX device. Similar surveys, in which the same methodology was used, have been carried out in many other regions (see Higueras et al. 2014, and references therein). The same sampling method was used to perform static TGM measurements in three fixed locations: (a) 


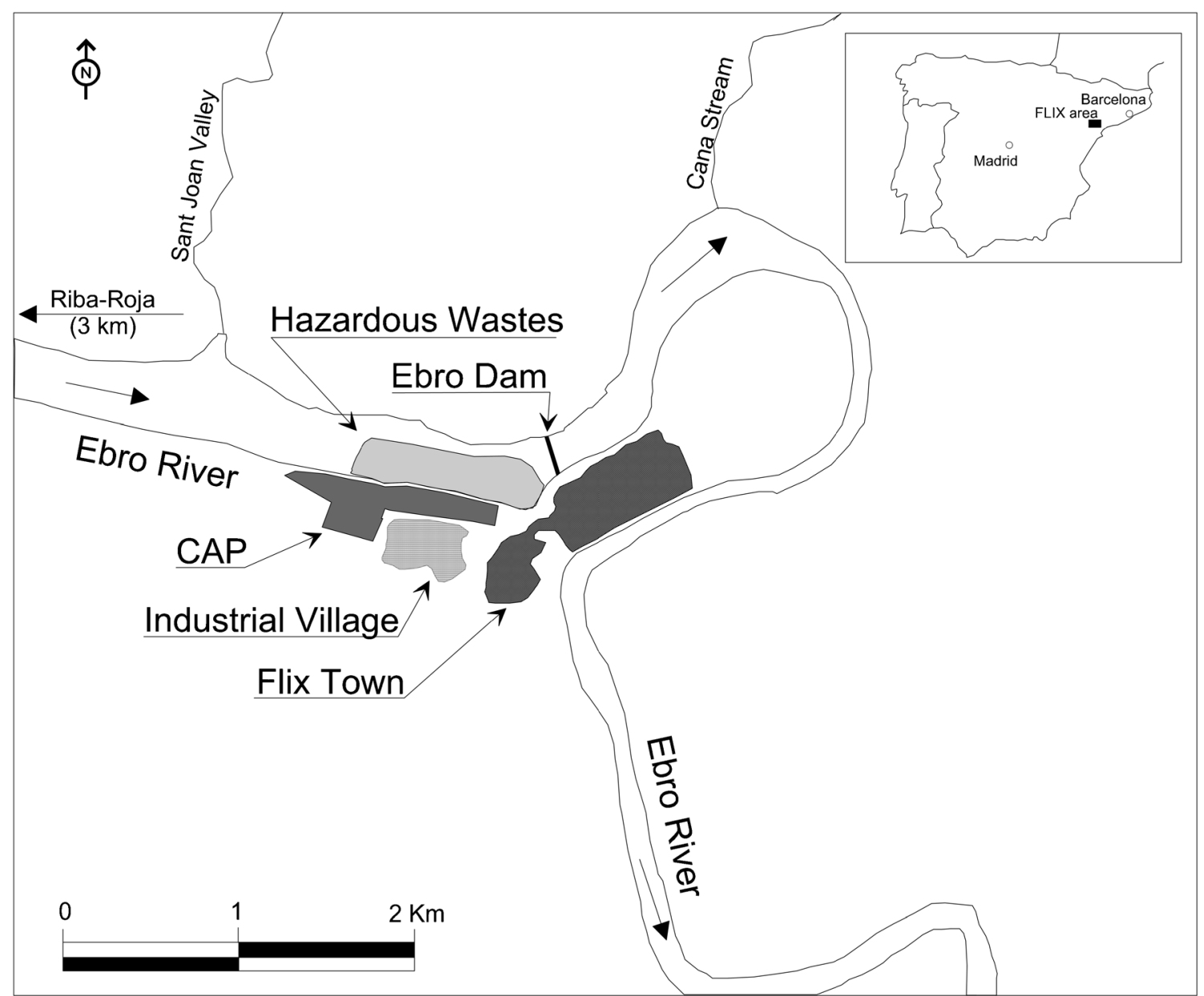

Fig. 1 Sketch map of the study area. Insert shows the general location with respect to Spain

the worker's village, located some $500 \mathrm{~m}$ from the CAP; (b) a house located in the centre of Flix town, some 2,000 m away from the CAP; and (c) Sebes facilities, on the opposite bank of Ebro River. In all TGM surveys, the equipment accuracy was checked prior to each measurement, and a baseline correction was made each $15 \mathrm{~min}$ to avoid effects due to fluctuations in lamp intensity. In parallel to all TGM determinations, local meteorological data were collected from a meteorological station located in Riba-Roja, which is located some $5 \mathrm{~km}$ NW of Flix; data collected included temperature, relative humidity, wind direction, wind speed, atmospheric pressure, and solar radiation.

Soil and sediment geochemical surveys were focused in two areas: one comprised the CAP area and its surroundings, and the second covered an anomalous area identified by the first survey at the Ebro margins, which was downstream from the town area (Fig. 2a). Soil and river bank sediment samples $(n=77)$ were taken from the topsoil layer $(0-20 \mathrm{~cm})$ in order to study dry and wet deposition of atmospheric mercury emitted by the CAP. Samples were collected using an Ejkelkamp stainless steel drill in a grid covering the study area and were stored in polyethylene bags prior to laboratory analysis. Sample preparation included air-drying, disaggregation, homogenization, sieving to a grain size $<2 \mathrm{~mm}$, and separation into three aliquots. Total mercury determinations were made by means of the ZAAS-HFM technique with a Lumex RA915+ device with a RP-91C pyrolysis attachment (Molina et al. 2006). Quality control was achieved by analysis of duplicate samples and certified reference materials (CRM: NIST-2710 and NIST 2711).

In order to validate the dispersion model for TGM, a lichen survey was carried out in the study area. Numerous factors affect the $\mathrm{Hg}$ uptake by bioindicators and the most important are distance from the source, mercury speciation in the atmosphere, temperature, solar radiation, wind conditions, local physiography, and interspecific differences in atmospheric Hg uptake patterns (Lodenius 2013). Moreover, Lippo et al. (1995) concluded that lichens seem to be more appropriate for local studies and mosses for regional studies. In order to avoid interspecific interferences, Xanthoria parietina Thalli was chosen due to its more ubiquitous nature in the study area. These foliose or leafy lichen samples were collected from branches of oak trees (Quercus rotundifolia L.) at 1.5-2 m 


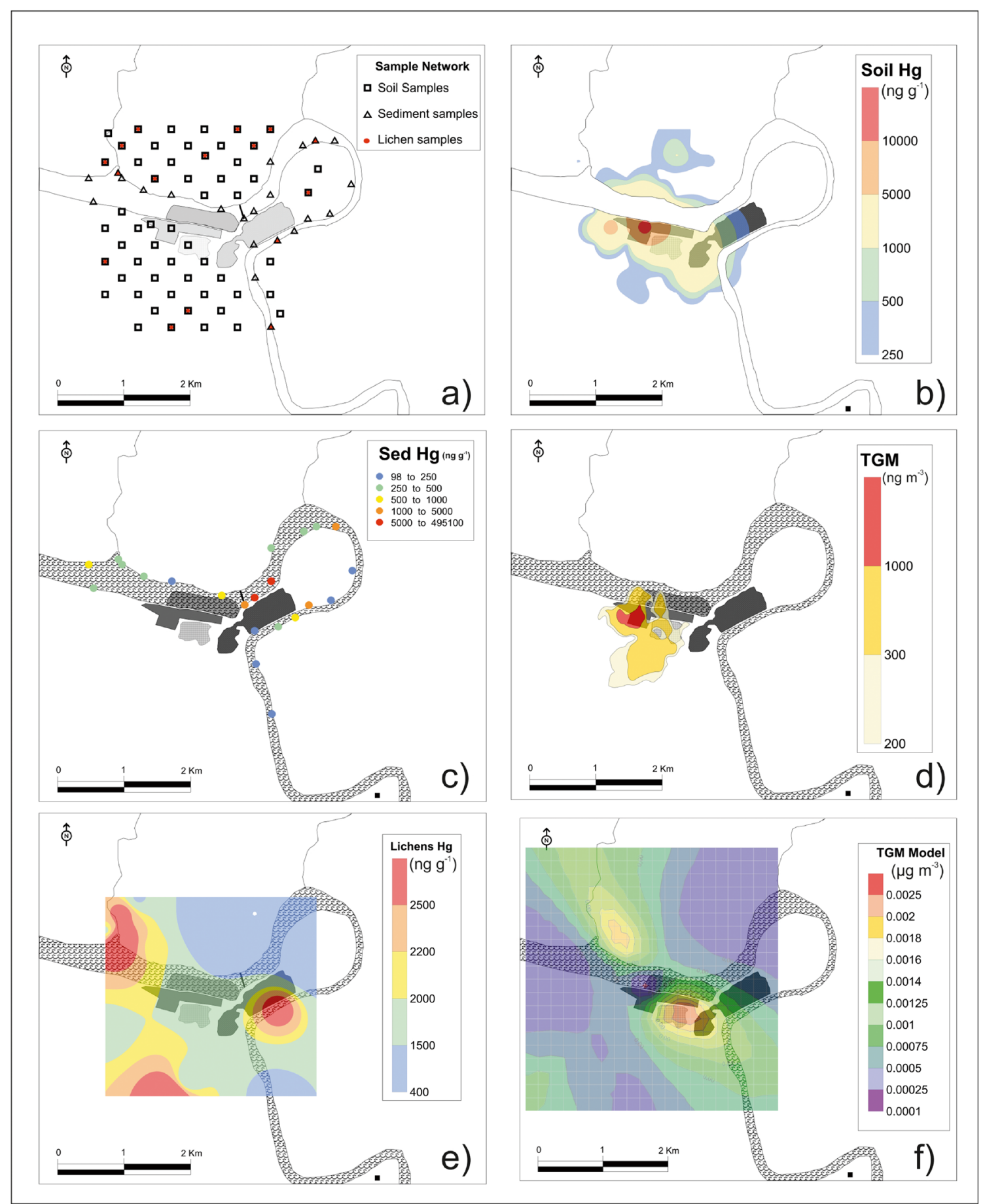

Fig. 2 (a) Sampling network of air, soils, sediments, and lichens, (b) Mercury contents in the soils, as obtained from kriging-based interpolation of measured data. Concentrations in $\mathrm{ng} \mathrm{g}^{-1}$, (c) mercury contents in the river bank sediments from the Ebro River margins. Concentrations in ng $\mathrm{g}^{-1}$, (d) mercury (TGM) concentrations in the local atmosphere, as obtained by kriging-based interpolation of all data from the 7 different surveys performed between 2007 and 2012. Concentrations in $\mathrm{ng} \mathrm{m}^{-3}$, (e)

above the ground with stainless steel tweezers, and samples were stored in paper bags prior to laboratory analysis. Sample preparation included thorough cleaning and freeze-drying

mercury concentrations in lichens, as obtained by kriging-based interpolation of measured analytical data. Concentrations in $\mathrm{ng} \mathrm{g}^{-1}$, (f) Theoretical model of $\mathrm{Hg}$ distribution in the local atmosphere, as obtained using the ISC AERMOD software, considering the Hg emissions to the atmosphere declared by the CAP to the Spanish PRTR Register. Concentrations in $\mu \mathrm{g} \mathrm{m}^{-3}$

before total mercury analysis by ZAAS-HFM in a Lumex RA-915 device with a PYRO-915 pyrolysis attachment (more details in Molina et al. 2006). The accuracy obtained 
Table 1 Statistics for data obtained in the TGM surveys

\begin{tabular}{llllll}
\hline & $\mathrm{N}$ & Min & Max & Average & GM \\
\hline Day hours (mobile surveys) & & & & & \\
$26 / 06 / 07$ & 6687 & 0.3 & 4793 & 52.8 & 9.7 \\
$27 / 06 / 07$ & 6188 & 0.0 & 4045 & 78.4 & 16.2 \\
$17 / 07 / 10$ & 4753 & 0.6 & 27,440 & 102.8 & 21.2 \\
$10 / 10 / 11$ & 8920 & 4.4 & 11,640 & 110.7 & 32.5 \\
$11 / 10 / 11$ & 9356 & 1.6 & 5901 & 323.9 & 47.2 \\
$11 / 12 / 12$ & 8986 & 0.8 & 1307 & 16.7 & 5.8 \\
$12 / 12 / 12$ & 6680 & 1.0 & 206 & 43.3 & 32.1 \\
Night hours (fixed locations) & & & & & \\
Sebes 11/12/12 & 32,571 & 1.0 & 13 & 3.9 & 3.5 \\
Flix town 13/10/11 & 33,982 & 1.0 & 297 & 20.5 & 9.7 \\
Workers village 11/10/11 $^{2}$ & 28,194 & 67.3 & 843 & 276.6 & 228.9 \\
Reference values & & & & & \\
Almadenejos $^{\mathrm{a}}$ & 1923 & 1 & 4996 & & \\
Almadén $^{\mathrm{a}}$ & 1148 & 1 & 2594 & & \\
Las Cuevas $^{\mathrm{a}}$ & 1964 & 1 & 9703 & & \\
Background level $^{\mathrm{b}}$ & & 2 & 3 & & \\
\hline
\end{tabular}

All mercury contents in $\mathrm{ng} \mathrm{m}^{-3}$

$N$ number of samples, $\min$ minimum value, $\max$ maximum value, average arithmetic mean, $G M$ geometric mean

${ }^{\text {a }}$ Data from Llanos et al. (2011)

${ }^{\mathrm{b}}$ Data from Wängberg et al. (2005)

by CRM-482 analyses was $100.8 \%$, while precision was $1.2 \%$.

The plume dispersion model developed by the US Environmental Protection Agency (USEPA 2009) (ISCAERMOD software) was used to predict concentrations of $\mathrm{Hg}$ in air. This model can simulate the dispersion of atmospheric pollutants from point and aerial source emissions (e.g., Orloff et al. 2006; Llanos et al. 2010, 2011). The dispersion model was constructed on the basis of topographical data and meteorological parameters during 2011 and averaged over 1-h periods of time.

\section{Results}

TGM concentration in air

The descriptive statistics for TGM concentrations in the surveyed area are shown in Table 1. The measured values reached maximum levels in summer $\left(27,440 \mathrm{ng} \mathrm{m}^{-3}\right.$ in 2010), but average levels were higher in autumn (323 $\mathrm{ng} \mathrm{m}^{-3}$ in 2011), probably due to higher atmospheric pressure conditions during these monitoring periods. The maximum TGM values are higher than those measured in Almadén, the largest mercury mining district worldwide
(Llanos et al. 2011). This implies that the Flix area is currently the most significant "hot spot" for TGM mercury emissions in Spain. Data from mobile surveys indicate that TGM contents in the atmosphere in Flix are not dependent on temperature and solar radiation, with similar geometric means in cold seasons (autumn and winter) and in summer. This is a typical scenario in industrial areas where metallic mercury is handled (Llanos et al. 2011) and anthropic emissions are the main factor, which is in fact more strongly linked to production rates than to meteorological conditions. These meteorological parameters (especially wind, temperature, and solar radiation) seem to control the dispersion patterns in the studied area. The average TGM concentrations in fixed locations are markedly higher in terms of geometric mean in the workers village located near to the CAP (Fig. 2d), with a value of $228.9 \mathrm{ng} \mathrm{m}^{-3}$. This could be related to more stable conditions during the night, when the mixing layer created during morning hours disappears and local winds are lower than during the day (ratio of wind speed: day/night=1.54 during 2011).

Soil and sediment geochemistry

The analytical results for $\mathrm{Hg}$ in local soils and sediments are shown in Table 2. Mercury dispersion around the CAP has different effects on the soils and river plain sediments. Dry and wet deposition seems to be the main input of $\mathrm{Hg}$ in soils for the non-fluvial area, as can be seen in Fig. 2b, and anomalous $\mathrm{Hg}$ contents are centered in the CAP. Mercury contents in soils are in the range $44-12,900 \mathrm{ng} \mathrm{g}^{-1}$, with an average concentration of $775 \mathrm{ng} \mathrm{g}^{-1}$, i.e., well above average levels of $38 \mathrm{ng} \mathrm{g}^{-1}$ in Europe (FOREGS 2005), $20 \mathrm{ng} \mathrm{g}^{-1}$ in Spain (IGME 2012), and in other areas of Spain such as the Basque country (230 $\mathrm{ng} \mathrm{g}^{-1}$ ) (IHOBE 1993) and Madrid (30 $\mathrm{ng} \mathrm{g}^{-1}$ ) (De Miguel et al. 2002). A histogram for the measured values is shown in Fig. 3; concentrations below 2,000 $\mathrm{ng} \mathrm{g}^{-1}$ can be considered as constituting a log-normal background population. Therefore, values above the $2,000 \mathrm{ng} \mathrm{g}^{-1}$ threshold should be considered as the anomalous population. The areas affected by anomalous concentrations are shown in red in Fig. 2b, and these are clearly distributed around the CAP area, showing a significant negative correlation with distance $(R=-$ 0.5 ). Mercury contents in the vicinity of the CAP were higher than those reported in similar CAP facilities, including the UK, 3,800 ng g ${ }^{-1}$ (Bull et al. 1977), Canada, 5,700 ng g (Temple and Linzon 1977), France, $260 \mathrm{ng} \mathrm{g}^{-1}$ (Probst et al. 1999), or in three European CAPs, $400 \mathrm{ng} \mathrm{g}^{-1}$ (Biester et al. 2002). The maximum values decrease with distance from the point of emission until the background levels are reached at some $1.5 \mathrm{~km}$.

Mercury contents in river plain sediments have a distribution that is consistent with the hazardous waste discharged from the Flix CAP to the Ebro River margins, with average mercury contents of $298 \mathrm{ng} \mathrm{g}^{-1}$ upstream from the CAP and 
Table 2 Main statistics for the results of soils, sediments, and lichens analysis

\begin{tabular}{llllll}
\hline & SED a & SED b & SED total & Soil & Lichens \\
\hline $\mathrm{N}$ & 6 & 16 & 22 & 55 & 17 \\
Min & 151 & 98 & 98 & 44 & 387 \\
Max & 508 & 495,000 & 495,000 & 12,900 & 3,750 \\
Average & 298 & 31,978 & 23,338 & 775 & 1,606 \\
GM & 279 & 776 & 587 & 228 & 1,264 \\
\hline
\end{tabular}

SED a: upstream sediments; SED b: downstream sediments; SED total: all sediments. All mercury contents in $\mathrm{ng} \mathrm{g}^{-1}$

$N$ number of samples, $\min$ minimum value, $\max$ maximum value, average arithmetic mean, $G M$ geometric mean

$31,978 \mathrm{ng} \mathrm{g}^{-1}$ downstream, with a concentration range in the polluted area of 98-495,000 $\mathrm{ng} \mathrm{g}^{-1}$. These concentrations are higher, particularly in the Flix meander (see Fig. 2c) downstream from the Ebro dam, and they are much higher than reported values in locations $50 \mathrm{~km}$ downstream from Flix (500-2,000 ng g ${ }^{-1}$ ) (Grimalt et al. 2003; Bosch et al. 2009).

Biomonitoring data

Lichens have been used a great deal as biomonitors in chloralkali plants (Sensen and Richardson 2002; Grangeon et al. 2012). Lichen species' similar to those used in the present study ( $X$. parietina) have proven to be a good indicator of long-term mercury dispersion patterns around an industrial facility (Grangeon et al. 2012) and in other $\mathrm{Hg}$ dispersion studies (Loppi et al. 2006). In the Flix CAP study area, $X$. parietina shows mercury levels (Table 2 ) in the range from 0.4 to $3.7 \mathrm{mg} \mathrm{kg}^{-1}$. The background content for $X$. parietina was $0.09 \mathrm{mg} \mathrm{kg}^{-1}$ (Cuny et al. 2004), i.e., much lower than the mercury contents found in the Flix area. Mercury contents in lichen samples can be interpreted as a reflection of long-term exposure (Garty 2000). In the area under investigation, correlations were not found between lichen $\mathrm{Hg}$ contents and distance to the CAP. It can be seen from Fig. 2e that three individual areas around the CAP have the highest $\mathrm{Hg}$ contents and physiography, and local wind directions are believed to be the main factors that affect these dispersion patterns.

Dispersion model

A model for the atmospheric $\mathrm{Hg}$ dispersion around the unique emission source was developed with ISC-AERMOD software. Emission data declared to the PRTR inventory were used together with topography and meteorological conditions to construct the model. As an analog to long-term exposure, a lapse time of 1 year was used to ascertain the mercury dispersion pattern (Fig. 2f). Three anomalous areas were found with good fitting for those areas with higher mercury contents in lichens (Fig. 2d), thus showing that $X$. parietina seems to be a good indicator of dispersion patterns of gaseous mercury around the facility.

\section{Discussion}

The CAP located at Flix town probably represents the major point source of $\mathrm{Hg}$ emissions in Spain today, not only contributing to the global pool of atmospheric mercury but also affecting the local population. In particular, Esbri et al. (2009) showed that Flix is the maximum emitter of gaseous mercury in comparison with all of the other Spanish CAPs; besides, Higueras et al. (2013) recently studied variations in mercury concentrations that affect the most important Spanish Hg mine (Almadén) and found significant reductions in pollution levels, which are actually much lower than the ones described here. The TGM levels up to the maximum level for chronic exposure (USEPA 1997) of $300 \mathrm{ng} \mathrm{m}^{-3}$ in the worker's village for all measurement days are represented in Fig. 2d. Even in the vicinity of the CAP, the levels are retained up to the
Fig. 3 Frequencies histogram for $\mathrm{Hg}$ distribution in the local soils

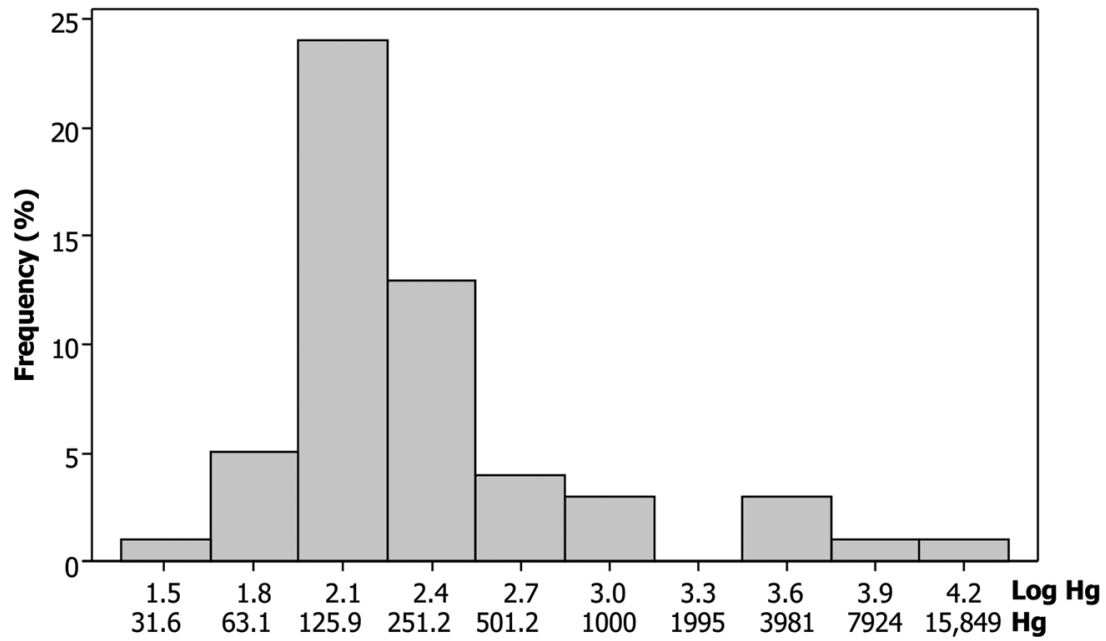


maximum recommended levels of $1,000 \mathrm{ng} \mathrm{m}^{-3}$ (WHO 2000).

Different $\mathrm{Hg}$ dispersion patterns were found in air and soil in this study. Mercury is present in the atmosphere in the forms of gaseous elemental mercury (GEM), reactive gaseous mercury (RGM), and particulate mercury (PM). RGM and PM are removed from the atmosphere by wet and dry deposition, while GEM is only affected by dry deposition (Wängberg et al. 2005). The results of this study provide total mercury data for air, soils, sediments, and lichens, and they show contrasting locations of anomalies in soils and in the atmosphere. This finding can be explained by differences in deposition rates between different mercury compounds in the atmosphere (Fig. 2b,d,e). Wängberg et al. (2005) showed that PM makes a very low contribution to $\mathrm{Hg}$ in source emissions such as CAP, while RGM could be present in low concentrations and may be deposited close to the emission source without any influence of topography and meteorological conditions. This explains the regular and reasonably concentric distribution of this form of $\mathrm{Hg}$ in the soils. The level of RGM in CAP emission sources is typically $2 \%$ (Landis et al. 2004), while only $2.4 \%$ of total mercury emitted by a CAP is deposited in surrounding soils (radius $=1 \mathrm{~km}$ ) (Biester et al. 2002). This atmospheric mercury species could be the major contributor to mercury contents in soils, although GEM has a longer residence time in the atmosphere (Wan et al. 2009; Gustin and Lindberg 2005) and travels further from the CAP mercury source and is controlled by topography and major wind directions. Thus, soils should be the main receptors of $\mathrm{PM}$ and RGM, a situation that explains the regular concentric distribution of $\mathrm{Hg}$ in the soils (Fig. 2b); In contrast, the long time spans for GEM distribution, as characterized by lichen contents (Fig. 2e), validate the theoretical annual dispersion model (Fig. 2f), which corresponds to the CAP acting as a source of this pollutant.

\section{Conclusions}

The high concentrations of mercury found particularly in the atmospheric compartment of Flix CAP may indicate that this area is the major point source of $\mathrm{Hg}$ pollution in Spain nowadays.

Moreover, this factory partially affects the Flix urban area, with values well above international thresholds for residential areas. Wet and dry Hg depositions are at their highest levels on the banks of the Ebro River and contribute to increased soil contamination. All of our atmospheric mercury dispersion models based on declared emissions display dispersion patterns that differ from those observed for soils. A comparison with mercury dispersion patterns in local lichens was also performed in order to validate our model, assuming that for lichens, mercury represents more than 1 year of exposure. A good fit was obtained between anomalous areas indicated by lichens and the dispersion model for 1 year.

Acknowledgments This study was funded by the Spanish Ministry of Economy and Competitiveness (Project CTM2012-33918). The authors would like to acknowledge Pere Josep Jiménez from the Grup Natura Freixe at Flix for his help during sampling campaigns. We also gratefully acknowledge the collaboration of Alba Martinez-Coronado, Leticia Baselga, and Silvia Palacios during some of the GEM surveys. Special thanks are also due to Dr. Jorge Jódar for supplying relevant meteorological data and Dr. Neil Thompson for revising the manuscript. Comments from two anonymous reviewers have helped to improve the final quality of this work.

\section{References}

Bellanger M, Pichery C, Aerts D, Berglund M, Castaño A, Čejchanová M, Crettaz P, Davidson F, Esteban M, Fischer ME, Gurzau AE, Halzlova K, Katsonouri A, Knudsen LE, Kolossa-Gehring M, Koppen G, Ligocka D, Miklavčič A, Reis MF, Rudnai P, Snoj Tratnik J, Weihe P, Budtz-Jørgensen E, Grandjean P, DEMO/COPHES (2013) Economic benefits of methylmercury exposure control in Europe: monetary value of neurotoxicity prevention. Environ Health 12(1):3

Biester H, Muller G, Scholer HF (2002) Estimating distribution and retention of mercury in three different soils contaminated by emissions from chlor-alkali plants: part I. Sci Total Environ 284:177-189

Bosch C, Olivares A, Faria M, Navas JM, del Olmo I, Grimalt JO, Pina B, Barata C (2009) Identification of water soluble and particle bound compounds causing sublethal toxic effects a field study on sediments affected by a chlor-alkali industry. Aquat Toxicol 94:16-27

Bull KR, Roberts RD, Inskip MJ, Godman GT (1977) Mercury concentrations in soils, grass, earthworms and small mammals near an industrial emission source. Environ Pollut 12:135-140

Busto Y, Tack FMG, Cabrera X (2013) Leaching behaviour of mercury from hazardous solid waste generated by chlor-alkali industry. In: Pirrone N (Editor), Proceedings of the 16th International Conference on Heavy Metals in the Environment. E3S Web of Conferences

Carrasco L, Diez S, Soto DX, Catalan J, Bayona JM (2008) Assessment of mercury and methylmercury pollution with zebra mussel (Dreissena polymorpha) in the Ebro River (NE Spain) impacted by industrial hazardous dumps. Sci Total Environ 407:178-184

Carrasco L, Bayona JM, Díez S (2010) Mercury in aquatic organisms of the Ebro River Basin, The Handbook of Environmental Chemistry. Springer-Verlag, Berlin Heidelberg

Carrasco L, Benejam L, Benito J, Bayona JM, Diez S (2011a) Methylmercury levels and bioaccumulation in the aquatic food web of a highly mercury-contaminated reservoir. Environ Int 37: 1213-1218

Carrasco L, Barata C, Garcia-Berthou E, Tobias A, Bayona JM, Diez S (2011b) Patterns of mercury and methylmercury bioaccumulation in fish species downstream of a long-term mercury-contaminated site in the lower Ebro River (NE Spain). Chemosphere 84:1642-1649

Clarkson TW, Magos L (2006) The toxicology of mercury and its chemical compounds. Crit Rev Toxicol 36:609-662

Cuny D, Davranche L, Thomas P, Kempa M, Van Haluwyn C (2004) Spatial and temporal variations of trace element contents in Xanthoria parietina Thalli collected in a highly industrialized area in Northern France as an element for a future epidemiological study. J Atmos Chem 49:391-401

De Miguel E, Callaba A, Arranz JC, Cala V, Chacón E, Galledo E, Alberruche E, Alonso C, Fernandez-Cantelli P, Iribarren I, 
Palacios H (2002) Determination of background and reference levels of metals and trace elements on Madrid soils. Ministerios de Ciencia y Tecnología. Consejería de Medio Ambiente. Instituto Geologico y Minero, Madrid (In Spanish)

Degetto S, Schintu M, Contu A, Sbrignadello G (1997) Santa Gilla lagoon (Italy): a mercury sediment pollution case study. Contamination assessment and restoration of the site. Sci Total Environ 204:49-56

Diez S (2009) Human health effects of methylmercury exposure. In: Whitacre DM (ed) Rev Environ Contam Toxicol 198:111-132

EC (2004) Mercury flows in Europe and the world: the impact of decommissioned chlor-alkali plants. Final report. European Commission. Directorate General for Environment. http://ec. europa.eu/environment/chemicals/mercury/pdf/report.pdf. Accessed 26 May 2014

EC (2008) No 1102/2008 of the European parliament and of the council of 22 October 2008 on the banning of exports of metallic mercury and certain mercury compounds and mixtures and the safe storage of metallic mercury. In: parliament E, TcoE Union, editors. Official Journal of the European Union, Strasbourg; 2008. (L304/75)

Esbri JM, Baselga L, Higueras P (2009) Evaluation of mercury dispersion from chlor-alkali industries in Spain. In: Theophanides M, Theophanides $\mathrm{T}$ (eds) Environmental Engineering and Management. Atiner, Atenas, pp 121-128

EuroClor (2012) http://www.eurochlor.org/media/69016/data_mercury balance 2012.pdf. Accessed 26 May 2014

FOREGS (2005) Geochemical Atlas of Europe, ed. R. Salminen, Finland, http://weppi.gtk.fi/publ/foregsatlas/maps/Subsoil/c_hg_edit.pdf. Accessed 20 Mar 2014

Frentiu T, Pintican BP, Butaciu S, Mihaltan AI, Ponta M, Frentiu M (2013) Determination, speciation and distribution of mercury in soil in the surroundings of a former chlor-alkali plant: assessment of sequential extraction procedure and analytical technique. Chem Cent J 7(1):178

Garty J (2000) Environment and elemental content of lichens. In: Markert B, Friese K (eds) Trace metals in the environment. Elsevier Science Publishers, Amsterdam, pp 245-276

Grangeon S, Guedron S, Asta J, Sarret G, Charlet L (2012) Lichen and soil as indicators of an atmospheric mercury contamination in the vicinity of a chlor-alkali plant (Grenoble, France). Ecol Indic 13: $178-183$

Grimalt JO, Sánchez-Cabeza JA, Palanques A, Catalán J (2003) Estudi de la dinàmica dels compostos organoclorats persistents $\mathrm{i}$ altres contaminants en els sistemes aquàtics continentals. CatalanWater Agency, Government of Catalonia, ACA/CIRIT; p. 256

Guedron S, Grangeon S, Jouravel G, Charlet L, Sarret G (2013) Atmospheric mercury incorporation in soils of an area impacted by a chlor-alkali plant (Grenoble, France): contribution of canopy uptake. Sci Total Environ 445:356-364

Gustin MS, Lindberg SE (2005) Terrestrial Hg fluxes: is the net exchange up, down, or neither? In: Pirrone N, Mahaffey KR (eds) Dynamics of mercury pollution on regional and global scales. Springer, New York, pp 241-253

Higueras P, Esbri JM, Oyarzun R, Llanos W, Martínez-Coronado A, Lillo J, Lopez-Berdonces MA, Garcia-Noguero E (2013) Industrial and natural sources of gaseous elemental mercury in the Almadén district (Spain): an updated report on this issue after the ceasing of mining and metallurgical activities in 2003 and major land reclamation works. Environ Res 125:197-208

Higueras P, Oyarzun R, Kotnik J, Esbrí JM, Martínez-Coronado A, Horvat M, López-Berdonces MA, Llanos W, Vaselli O, Nisi B, Mashyanov N, Ryzov V, Spiric Z, Panichev N, McCrindle R, Feng X, Fu W, Lillo J, Loredo J, García ME, Alfonso P, Villegas K, Palacios S, Oyarzún J, Maturana H, Contreras F, Adams M, Ribeiro-Guevara S, Niecenski LF, Giammanco S, Huremović J (2014) A compilation of field surveys on gaseous elemental mercury
(GEM) from contrasting environmental settings in Europe, South America, South Africa, and China: separating fads from facts. Environ Geochem Health. 36:713-734 doi:10.1007/s10653-0139591-2

IGME (2012) Geochemical atlas of Spain, Instituto Geológico y Minero de España, Madrid (In Spanish)

IHOBE (1993) Soil pollution research vol 8. Soil quality. Departamento de Medio Ambiente y Ordenación del territorio, Gobierno Vasco, Vitoria (In Spanish)

Landis MS, Keeler GJ, Al-Wali KI, Stevens RK (2004) Divalent inorganic reactive gaseous mercury emissions from a mercury cell chloralkali plant and its impact on near-field atmospheric dry deposition. Atmos Environ 38:613-622

Lippo H, Poikolainen J, Kubin E (1995) The use of moss, lichen and pine bark in the nationwide monitoring of atmospheric heavy metal deposition in Finland. Water Air Soil Pollut 85:2241-2246

Llanos W, Higueras P, Oyarzun R, Esbrí JM, López-Berdonces MA, García-Noguero EM, Martínez-Coronado A (2010) The MERSADE (European Union) project: testing procedures and environmental impact for the safe storage of liquid mercury in the Almadén district, Spain. Sci Total Environ 408:4901-4905

Llanos W, Kocman D, Higueras P, Horvat M (2011) Mercury emission and dispersion models from soils contaminated by cinnabar mining and metallurgy. J Environ Monitor 13:3460-3468

Lodenius M (2013) Use of plants for biomonitoring of airborne mercury in contaminated areas. Environ Res 125:113-123

Loppi S, Paoli L, Gaggi C (2006) Diversity of epiphytic lichens and Hg contents of Xanthoria parietina Thalli as monitors of geothermal air pollution in the Mt. Amiata area (Central Italy). J Atmos Chem 53(2):93-105

Mergler D, Anderson HA, Chan LHM, Mahaffey KR, Murray M, Sakamoto M, Stern AH (2007) Methylmercury exposure and health effects in humans: a worldwide concern. Ambio 36:3-11

Molina JA, Oyarzun R, Esbrí JM, Higueras P (2006) Mercury accumulation in soils and plants in the Almadén mining district, spain: one of the most contaminated sites on earth. Environ Geochem Health 28(5):487-498

Montuori P, Jover E, Diez S, Ribas-Fito N, Sunyer J, Triassi M, Bayona JM (2006) Mercury speciation in the hair of pre-school children living near a chlor-alkali plant. Sci Total Environ 369:51-58

Navarro A, Quiros L, Casado M, Faria M, Carrasco L, Benejam L, Benito J, Diez S, Raldua D, Barata C, Bayona JM, Pina B (2009) Physiological responses to mercury in feral carp populations inhabiting the low Ebro River (NE Spain), a historically contaminated site. Aquat Toxicol 93:150-157

Nik MG, Shahbazi B, Grigoryan K (2012) The study of mercury pollution distribution around a chlor-alkali petrochemical complex, Bandar Imam, southern Iran. Environ Earth Sci 67:1485-1492

Orloff KG, Kaplan B, Kowalski P (2006) Hydrogen cyanide in ambient air near a gold heap leach field: measured vs. modelled concentrations. Atmos Environ 40:3022-3029

Pacyna JM, Sundseth K, Pacyna EG, Jozewicz W, Munthe J, Belhaj M, Aström S (2010) An assessment of costs and benefits associated with mercury emission reductions from major anthropogenic sources. J Air Waste Manag 60(3):302-315

Pirrone N, Cinnirella S, Feng X, Finkelman RB, Friedli HR, Leaner J, Mason R, Mukherjee AB, Stracher GB, Streets DG, Telmer K (2010) Global mercury emissions to the atmosphere from anthropogenic and natural sources. Atmos Chem Phys 10:59515964

Probst J L, Prudent P, Stastna M, Probst A, Frevier C, Party JP, Krempp G (1999) Spatial variation of mercury contents in soils, river sediments and river waters in the Strengbach catchment (northeastern France), Proc. 5th Conf. Mercury as a Global Pollutant, Rio de Janeiro, 168

Selin NE (2009) Global biogeochemical cycling of mercury: a review. Annu Rev Environ Resour 34:43-63 
Sensen M, Richardson DHS (2002) Mercury levels in lichens from different host trees around a chlor-alkali plant in New Brunswick, Canada. Sci Total Environ 293:31-45

Sholupov S, Pogarev S, Ryzhov V, Mashyanov N, Stroganov A (2004) Zeeman Atomic absorption spectrometer RA-915+ for direct determination of mercury in air and complex matrix samples. Fuel Process Technol 85:473-485

Temple PJ, Linzon (1977) Contamination of vegetation, soil, snow and garden grops by atmospheric deposition of mercury from a Chloralkali plant. In Hemphill DD (ed) 11th Annual conference on trace substances in environmental health. University of Missouri Press, Columbia, pp 389-398

UNEP (2010) Study on the possible effects on human health and the environment in Latin America and the Caribbean of the trade of products containing cadmium, lead and mercury. http://www.unep. org/chemicalsandwaste/Portals/9/Lead Cadmium/docs/Trade Reports/AP/UNEPLeadPb-CaicedoCompilation110601.pdf. Accessed 26 May 2014

UNEP (2013) Global mercury assessment 2013: sources, emissions, releases and environmental transport. UNEP Chemicals Branch, Geneva
USEPA (1997) Mercury study report to Congress (volume V: health effects of mercury and mercury compounds). EPA-452/R-97-007 V. United States Environmental Protection Agency, Washington DC, USA, www.epa.gov/hg/report.htm. Accessed 4 Dec 2014

USEPA (2009) Aermod implementation Guide. http://www.epa.gov/ttn/ scram/7thconf/aermod/aermod_implmtn_guide_19March2009.pdf. Accessed 4 Dec 2014

Wan Q, Feng X, Lu J, Zheng W, Song X, Li P, Han S, Xu H (2009) Atmospheric mercury in Changbai Mountain area, northeastern China II. The distribution of reactive gaseous mercury and particulate mercury and mercury deposition fluxes. Environ Res 109:721-727

Wängberg I, Barregard L, Sällsten G, Haeger-Eugensson M, Munthe J, Sommar J (2005) Emissions, dispersion and human exposure of mercury from a Swedish chlor-alkali plant. Atmos Environ 39: $7451-7458$

WCC (2013) http://www.eurochlor.org/chlorine-industry-issues/mercury. aspx. Accessed 26 May 2014

WHO (2000) Air Quality Guidelines for Europe. WHO Regional Publications European Series 91, World Health Organization Regional Office for Europe, Copenhagen, 288 pp 